\title{
Analysis of Plans for Rainwater Reuse in a Residential Area in Jiangsu, China
}

\author{
Shucong Zhen \\ Yancheng Institute of technology \\ Yancheng 224051, China \\ e-mail: zhenshucong@163.com
}

Yong Xun

Yancheng Institute of technology

Yancheng 224051, China

Shanghai LanTian Decoration Engineer Limited

Corporation

Shanghai,200433, China

Suzhou University of Science and Technology

Suzhou, 215000, China

e-mail: zhenshucong@163.com

\author{
$\operatorname{Simin} \mathrm{Xu}$ \\ Shanghai LanTian Decoration Engineer Limited \\ Corporation \\ Shanghai,200433, China \\ e-mail: zhenshucong@163.com
}

\author{
Yougxin Zhou \\ Suzhou University of Science and Technology \\ Suzhou, 215000, China \\ *zhenshucong@163.com
}

\begin{abstract}
To make full use of rainwater resources, and to reduce the environmental stress brought about by rainwater drainage, rainwater sampled in a residential area in Yancheng City, Jiangsu Province was treated by four processes: (1)rainwater $\rightarrow$ sand $\rightarrow$ filtration $\rightarrow$ disinfection $\rightarrow$ disc harge;(2)rainwater $\rightarrow$ coagulation $\rightarrow$ sedimentation $\rightarrow$ disinfecti on $\rightarrow$ discharge; (3)rainwater $\rightarrow$ mesh $\rightarrow$ filtration $\rightarrow$ sand $\rightarrow$ filtra tion $\rightarrow$ disinfection $\rightarrow$ discharge; (4)rainwater $\rightarrow$ constructed $\rightarrow$ w etland $\rightarrow$ discharge. The results showed that effluent quality of the former three processes could meet the requirements of the reuse of urban recycling water-Water quality standard for urban miscellaneous water consumption (GB/T189202002). Process 2 and process 4 excelled in water quality and cost-effectiveness respectively. With the generalized analysis and comparison, the fourth process was recommended for rainwater reuse in residential areas.
\end{abstract}

Keywords-rainwater utilization; residential area; process; economic benefit analysis.

\section{INTRODUCTION}

Rainwater resources, which are abundant in China with the annual rainfall of $6.2 \times 10^{12} \mathrm{~m}^{3}$, concentrate in the southern Yangtze-Huaihe River basin. Meanwhile, more than $80.4 \%$ of the water resources are distributed in southern China (per capita: $3481 \mathrm{~m}^{3}$ )[1]. Therefore, the urban environment therein is being seriously affected by the direct discharge of rainwater other than harvesting and utilization owing to overwhelming urbanization and the relatively sluggish construction of urban water supply and drainage facilities[2-6]. However, southern China, which is most densely populated and industrially advanced nationwide, is thus suffering from severe quality-induced water shortage. The status quo will even deteriorate with further industrialization and urbanization. The sufficient rainfall in southern China, in case of being effectively harvested and used, will inevitably function in circumventing urban water resource shortage. As stipulated in "Engineering Technical Code for Rain Utilization in Building and Sub-district"(GB50400-2006), a rainwater utilization project is only qualified when the designed capacity of discharge in a construction land does not exceed the level or the specified value prior to development and construction. According to local conditions, rainwater that can be harvested by individual or combined strategies (e.g. reuse system, infiltration system and discharge-regulating system) is mainly used for landscape, greening, and miscellaneous, etc.

Some foreign countries government agencies have developed policies to strengthen the rainwater utilization, for example, In India, several state governments require to set up a rainwater collection system for the urban areas of the building roof, and the government will give the corresponding subsidy. In developed countries, such as Germany, Denmark, Australia and New Zealand, et al, the building roof rainwater was collected to flush the toilets to saving the valuable drinking water[7, 8]. In the rainwater recycling process, poor water quality caused by the roof material properties [9], the microorganisms in the collected rainwater, physicochemical properties and heavy metals [10-12] are the main problems of the rainwater recycling. Rainwater was collected from the roof should first remove large size debris through the grid or mesh to reduce the burden of the subsequent processing when collect the roof rainwater. The initial $5 \mathrm{~mm}$ rainfall should set the primary settling tank for precipitation, not only will the sediment particle deposition, but also can make the initial rainwater organic concentration with rainwater collection[13,14]. Subsequent treatment should be disinfected and even use the membrane process as the main treatment process, thereby increasing the use of space of rainwater reuse[15].

Rapid urbanization aggravates the negative effects of rainwater by considerably enlarging water-impermeable areas via substituting the original loose and ventilated 
surfaces for waterproof materials covered thereon, thus blocking the penetration of rainfall/flood into underground soil. Consequently, urban hydrologic cycle is evidently changed because rainfall runoff is prone to pipeline discharge rather than natural infiltration. Thus, it is imperative to find out a feasible protocol to dispose or utilize rainwater. Thereby motivated, taking the rainfall in a residential area in Yancheng City, Jiangsu Province as an example, this study treated rainwater by different processes and performed economic analysis, aiming to provide evidence and technical support for rainwater utilization

\section{MATERIALS AND METHODS}

\section{A. Sampling site and methods}

Rainwater was collected from a residential area in Tinghu District, Yancheng City, Jiangsu Province. Throughout the rainfall event, rainwater was manually sampled at the opening of rainwater downpipe. $5 \mathrm{~L}$ of water was sampled continuously by a polyethylene bottle (1L) $30 \mathrm{~min}$ before the formation of runoff. In the midst of runoff formation, about $15 \mathrm{~L}$ of water was sampled continuously from $30 \mathrm{~min}$ to $60 \mathrm{~min}$, and another $15 \mathrm{~L}$ was sampled continuously from $60 \mathrm{~min}$ to $120 \mathrm{~min}(\geq 20 \mathrm{~L}$ each time).In the meantime, the rainfall characteristics were synchronously recorded by an SJL siphon rain gauge that was installed approximately $500 \mathrm{~m}$ straight-line distance away from the sampling site.

\section{B. Measurements of indices}

All samples were sent to our laboratory timely for water quality analysis. $\mathrm{COD}, \mathrm{BOD}_{5}, \mathrm{SS}, \mathrm{NH}_{3}-\mathrm{N}, \mathrm{TP}$ and $\mathrm{TN}$ were measured by standard methods, and the concentrations of heavy metal ions such as $\mathrm{Cu}, \mathrm{Zn}, \mathrm{Pb}$ and $\mathrm{Cd}$ were measured by ICP after nitric acid digestion[16].

\section{Rainfall characteristics}

The rainfall event occurred on 13th July 2012 during which the amount was $198.7 \mathrm{~mm}$ and the maximum intensity was $0.7103 \mathrm{~mm} / \mathrm{min}$. The last rainfall and this rainfall time interval were 53.4 hours, temperature was $27.2^{\circ} \mathrm{Cand} \mathrm{pH}$ value was 7.7 , rainwater runoff time were 135 minutes.

\section{Process selection and laboratory process simulation}

Plan 1: Rainwater $\rightarrow$ storage $\quad$ pool $\rightarrow$ sand filtration $\rightarrow$ disinfection $\rightarrow$ miscellaneous water use

Laboratory simulation: Rainwater $\rightarrow$ sand filtration $\rightarrow$ disinfection $\rightarrow$ effluent discharge

Plan 2:

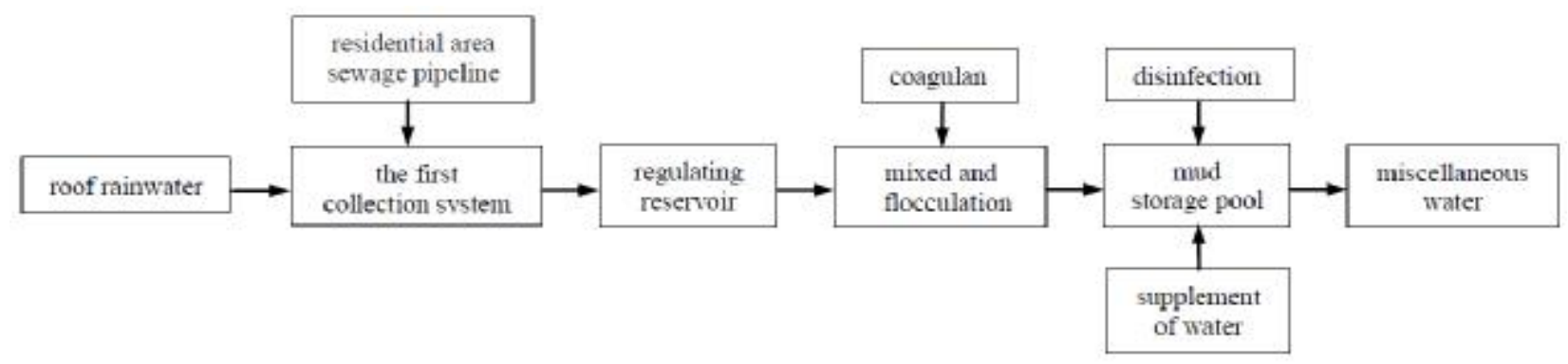

Laboratory simulation: Rainwater $\rightarrow$ coagulation $\rightarrow$ sedimentation $\rightarrow$ disinfection $\rightarrow$ effluent discharge Plan 3:

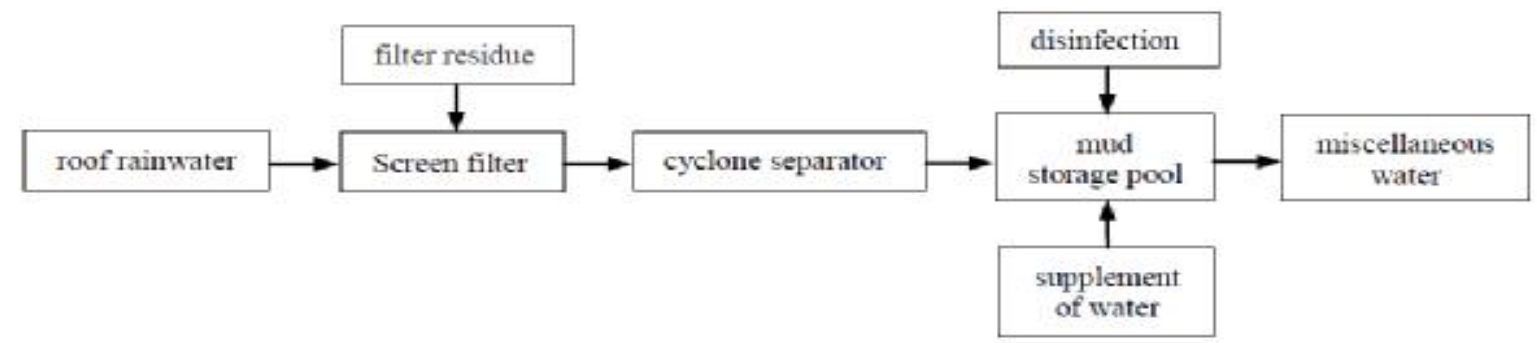

Laboratory simulation: Rainwater $\rightarrow$ mesh filtration $\rightarrow$ sand $\quad$ filtration $\rightarrow$ disinfection $\rightarrow$ effluent discharge

Plan 4: natural purification using ecological green spaces in the residential area

Laboratory simulation: Rainwater $\rightarrow$ constructed wetland $\rightarrow$ effluent discharge

The coagulation test was performed by a six-position stirrer, by which the optimum adding amount of the coagulant polyaluminium chloride was determined. Sand filtration was conducted by a $60 \mathrm{~cm}$-height sand column uniformly filled with fine quartz sands. Sodium hypochlorite was used for disinfection, and the constructed wetland vegetation comprised green grasses in the residential area.

\section{RESULTS AND ANALYSIS}

\section{A. Event mean concentrations (EMCs)}

The main title (on the first page) should begin $13 / 16$ inches ( 7 picas) from the top edge of the page, centered, and in Times New Roman 14-point, boldface type. Capitalize the first letter of nouns, pronouns, verbs, adjectives, and adverbs; do not capitalize articles, coordinate conjunctions, or prepositions (unless the title begins with such a word). Please initially capitalize only the first word in other titles, including section titles and first, second, and third-order headings (for example, "Titles and headings" — as in these guidelines). Leave two blank lines after the title. 
Table 1: average concentration of rain component(EMCs)(mg/L)

\begin{tabular}{|c|c|c|c|c|c|c|c|c|c|c|c|c|c|}
\hline $\begin{array}{c}\text { water quality } \\
\text { index }\end{array}$ & $S S$ & $B_{5}$ & $C O D$ & $N H_{3}-N$ & $T N$ & $T P$ & oil & $P b$ & $C u$ & $Z n$ & $C d$ & $F e$ & $M n$ \\
\hline concentration & 132 & 18 & 137 & 1.21 & 3.84 & 0.31 & 8.7 & 0.02 & 0.02 & 0.2 & - & 0.78 & 0.02 \\
\hline SD & 1.48 & 0.04 & 0.86 & 0.11 & 0.22 & 0.07 & 1.11 & 0.22 & 0.22 & 0.16 & 0 & 0.59 & 0.13 \\
\hline
\end{tabular}

\section{B. Processing effects}

The result of laboratory simulation treatment process was shown in Table 2.

Table 2: treatment result $(\mathrm{mg} / \mathrm{L})$

\begin{tabular}{|c|c|c|c|c|c|}
\hline $\begin{array}{l}\text { water quality } \\
\text { index }\end{array}$ & $\begin{array}{c}\text { standard } \\
\text { limit(car } \\
\text { wash) }\end{array}$ & $\begin{array}{c}\text { plan } \\
1\end{array}$ & $\begin{array}{c}\text { plan } \\
2\end{array}$ & $\begin{array}{c}\text { plan } \\
3\end{array}$ & $\begin{array}{c}\text { plan } \\
4\end{array}$ \\
\hline$T D S$ & 1000 & 963 & 524 & 678 & 981 \\
\hline $\mathrm{BOD}_{5}$ & $\leq 10$ & 8 & - & 7 & 3 \\
\hline$C O D$ & null & 46 & 23 & 41 & 20 \\
\hline $\mathrm{NH}_{3}-\mathrm{N}$ & $\leq 10$ & 0.73 & 0.38 & 0.69 & 0.21 \\
\hline$p H$ & $6.0-9.0$ & 7.3 & 7.2 & 7.7 & 7.5 \\
\hline chromaticity & $\leq 30$ & 27 & 15 & 20 & 17 \\
\hline smell & $\begin{array}{c}\text { no } \\
\text { displeasure }\end{array}$ & null & null & null & null \\
\hline turbidity/NTU & $\leq 5$ & 5 & 3 & 5 & 4 \\
\hline$T N$ & null & 1.74 & 0.85 & 1.71 & 0.62 \\
\hline$T P$ & null & 0.25 & 0.05 & 0.22 & 0.03 \\
\hline oil & null & 1.8 & 0.87 & 1.2 & 0.31 \\
\hline $\mathrm{Pb}$ & null & 0.01 & - & 0.01 & - \\
\hline $\mathrm{Cu}$ & null & 0.01 & - & 0.01 & - \\
\hline $\mathrm{Zn}$ & null & 0.11 & 0.07 & 0.10 & 0.04 \\
\hline $\mathrm{Fe}$ & $\leq 0.3$ & 0.18 & 0.07 & 0.11 & 0.15 \\
\hline$M n$ & $\leq 0.1$ & - & - & - & - \\
\hline $\begin{array}{c}\text { total coliform } \\
\text { bacteria/L }\end{array}$ & $\leq 3.0$ & - & - & - & 5 \\
\hline
\end{tabular}

Note: 1. "-" represents undetectable.2. The most stringent standard limit for vehicle wash water was referred to herein.3. "null" represents unrequired in standard limits.

Plan 2 outweighed others in satisfying the water quality standard for vehicle washing stipulated in "Reuse of Recycling Water for Urban/Water Quality Standard for Urban Miscellaneous Water Consumption" (GB/T189202002). However, Plan 2, which gave rise to slightly more coliform bacteria, must involve disinfection in prospective application. The effluents derived from Plan 2 and Plan 3 are eligible for toilet flushing, urban greening, vehicle washing, and construction, etc.

\section{Cost analysis}

Popularizing and applying a rainwater processing project are dominated by its overall cost and the benefit estimation on reuse posterior to processing. The construction investments and cost analyses of the plans are listed below.

(1) Construction investment analysis

Considering the inhomogeneity and uncertainty of rainwater, as well as the operational safety and economic practicality, the volume of water tank is designed according to the one-year recurrence interval (a $500 \mathrm{~m}^{3}$ storage pool and a $150 \mathrm{~m}^{3}$ clean water tank), exceeding which rainwater is discharged to municipal pipelines by water tank overflowing. The water tank, originally designed uncovered, costs 350 CNY per cubic meter(including direct and other expenses). The storage pool costs $175,000 \mathrm{CNY}$. The clean water tank costs about
$400 \mathrm{CNY}$ per cubic meter (including direct and other expenses), and the construction expense is 70,000 CNY.Constructing purification tanks in Plan 1-4 costs approximately 100,000, 170,000, 130,000 and 50,000 CNY respectively, and their total project investments are $375,000,445,000,405,000$ and 325,000 CNY respectively.

(2) Cost analysis

a. Investment depreciation: Reuse and purification systems are depreciated referring to the 50-year service life, by which the annual depreciation expenses of the four plans are calculated as 7,500, 8,900, 8,100 and 6,500 CNY respectively. In case of $15,000 \mathrm{~m}^{3}$ of runoff annually, the depreciation expenses per cubic meter of water are $0.50,0.59,0.54$ and $0.43 \mathrm{CNY} / \mathrm{m}^{3}$ respectively.

b. Operating expenses

Electric power charges: Plan 1-4 consume 0.3, 0.5, 0.2 and $0.1 \mathrm{kw}$ of electric power per cubic meter of rainwater respectively, and they finally cost $0.17,0.28,0.11$ and $0.06 \mathrm{CNY} / \mathrm{m}^{3}$ by being multiplied with $0.55 \mathrm{CNY}$ (electric power charge per kilowatt-hour).

Equipment maintenance and replacement expenses:

Assuming equipments are maintained and ecological green spaces are replanted once a year, the annual maintenance cost is about 2,000 CNY, the water charge is $0.13 \mathrm{CNY} / \mathrm{m}^{3}$ per cubic meter, and the direct operating expenses are $0.30,0.41,0.24$ and $0.19 \mathrm{CNY} / \mathrm{m}^{3}$ respectively in total.

c. The comprehensive costs per cubic meter of water for reuse and utilization are $0.80,1.00,0.78$ and 0.62 $\mathrm{CNY} / \mathrm{m}^{3}$ respectively. Assuming tap water costs $2.5 \mathrm{CNY}$ per cubic meter, 5,500, 22,500, 25,800 and 28,200 CNY are saved respectively annually.

The results suggest that utilizing rainwater in the residential area may directly create economic benefits.

\section{CONCLUSION}

1) The effluent quality of the former three processes could all meet the requirements of the reuse of urban recycling water-Water quality standard for urban miscellaneous water consumption (GB/T18920-2002). The number of total coliforms in the fourth effluent was $5 / \mathrm{L}$, which was beyond the limits $(3 / \mathrm{L})$ of the vehicle washing in the former standard, but it still could be used for toilet flushing, trees watering and construction building.

2) Among the four process, the construct cost of process 2 was the highest, which was about 445000 Yuan. However, the benefit of it was the lowest for saving the cost of piped water by the water reuse, which was about 22500 Yuan/year. On the contrary, the construct cost and the benefit of process 4 were 325000 Yuan and 28200 Yuan, which were the lowest and the highest respectively. The construct costs and benefits of the other two processes were between those of the second and the fourth process.

3) The process of the rainwater treatment should be selected according to practical situations for rainwater 
reuse in residential areas. Process 4 was recommended for its low energy consumption and environmental destruction, convenient materials obtaining and low construction cost.

\section{ACKNOWLEDGEMENT}

This work was supported byMinistry of Housing and Urban-Rural Development of the People's Republic of China research and development projects (2011-R2-24) and China Building Materials Industry Association technology innovation projects(2013-M5-2).

\section{REFERENCES}

[1] Wang H Z \& Li X F, Pollution of Run off from Beijing Urban Area and Its Control.URBANENVIRONMENT\&URBANECOLOGY. 2(15), 16-18, 2002.

[2] Li J Q, Che W and Meng G H, Design and Techno-Economical Analysis on Urban Rain Water Utilization. Water\& WastewaterEngineering. 27(12), 25-28,2001.

[3] Zhang K F, Fu D F and $\mathrm{Li} \mathrm{H}$, Comparison and analysis characteristics of PHAs pollution for different types of roof runoff. JOURNAL OF SOUTHEAST UNIVERSITY(Natural Science Edition). 42(1), 99-103, 2012.

[4] Chang M, McBroom M W and Scott Beasley R, Roofing as a source of nonpoint water pollution. Journal of Environmental Management. 73(4), 307-315, 2004.

[5] Lee J Y, Bak G and Han M. Quality of roof-harvested rainwater Comparison of different roofing materials. Environmental Pollution. 162(0), 422-429, 2012.

[6] Vialle C, Sablayrolles C and Lovera Ml. Monitoring of water quality from roof runoff: Interpretation using multivariate analysis. Water Research. 45 (12), 3765-3775, 2011.
[7] Schuetze T.. Rainwater harvesting and management-policy and regulations in Germany. WATER SCIENCE AND TECHNOLOGY-WATER SUPPLY. 13 (2), 57-68, 2013.

[8] Mikkelsen P S, Adeler O F, Albrechtsen H J and Henze, Collected rainfall as a water source in Danish households - What is the potential and what are the costs. WATER SCIENCE AND TECHNOLOGY. 39(5), 32-41, 1999.

[9] Matos C, Santos C, Pereira S, Bentes, I and Imteaz, Monzur, Rainwater storage tank sizing: Case study of a commercial building. International Journal of Sustainable Built Environment. 2(2), 726$732,2013$.

[10] Huston R, Chan Y C, Chapman H, Gardner, T and Shaw, G, Source apportionment of heavy metals and ionic contaminants in rainwater tanks in a subtropical urban area in Australia. Water Research. 46 (4), 3245-3254, 2012.

[11] Kabir M I, Daly E and Maggi F. A review of ion and metal pollutants in urban green water infrastructures. Science of The Total Environment, 470-471 (0), 399-403, 2014

[12] Tiwari S, Chate D M, Bisht D S, Srivastava, M K and Padmanabhamurty, B, Rainwater chemistry in the North Western Himalayan Region, India. Atmospheric Research. 104-105 (0) ,128-138, 2012.

[13] Bach P M, McCarthy D T and Deletic A, Redefining the stormwater first flush phenomenon Water Research. 44 (8), 36-48, 2010.

[14] Gikas G D and Tsihrintzis V A, Assessment of water quality of first-flush roof runoff and harvested rainwater. Journal of Hydrology. 466-467(0), 2142-2151, 2012.

[15] Adler I, Hudson-Edwards K Aa and Campos L C, Converting rain into drinking water: quality issues and technological advances. WATER SCIENCE AND TECHNOLOGY-WATER SUPPLY. 11(6), 61-72, 2011.

[16] Water and wastewater monitoring method editorial committee, Editor. Water and wastewater monitoring method. Beijing: China $\begin{array}{lll}\text { environment science } & \end{array}$ 